\title{
Design and Construction of Deep Excavations
}

\author{
Barham J. Nareeman ${ }^{1 \&}$ Asmaa Abdulmajeed Mamhusseini ${ }^{2}$
}

\author{
${ }^{1}$ Independent Researcher \\ ${ }^{2}$ Civil Engineering Department, Faculty of Engineering, Tishk International University, Erbil, Iraq \\ Correspondence: Asmaa.abdulmajeed Mamhusseini, Tishk International University, Erbil, Iraq. \\ Email: asmaa.abdulmajeed@ tiu.edu.iq
}

$$
\text { doi: 10.23918/eajse.v6i1p75 }
$$

\begin{abstract}
Excavations in urban developed area are generally supported by deep excavation walls such as; diaphragm wall, bored piles, soldier piles and sheet piles. In some cases, these walls may be braced by internal braces or tie back anchors. Tie back anchors are by far the predominant method for wall support, the large working space inside the excavation provided by a tieback anchor system which has a significant construction advantage. This paper aims to analyze a deep excavation bracing system of contiguous pile wall braced by pre-stressed tie back anchors, which is a part of a huge residential building project, located in Turkey/Gaziantep province. The contiguous pile wall will be constructed with a length of $270 \mathrm{~m}$ that consists of 285 piles, each having a diameter of $80 \mathrm{~cm}$, and a center to center spacing of $95 \mathrm{~cm}$. The deformation analysis was carried out by available finite element analysis tool using PLAXIS. In the analysis, beam element method together with an elastic perfect plastic soil model and Soil Hardening Model was used to design the contiguous pile wall, the tieback anchor system and the soil. The two soil clusters which are limestone and a filled soil were modeled with both Hardening soil and Mohr Coulomb models. According to the basic design, both soil clusters are modeled as drained condition. The simulation results show that the maximum horizontal movement of the walls and the maximum settlement of the ground are convenient with 300 individual case histories which are ranging between $1.2 \mathrm{~mm}$ and $2.3 \mathrm{~mm}$ for walls, and $15 \mathrm{~mm}$ and $6.5 \mathrm{~mm}$ for the settlements. It was concluded that tied-back contiguous pile wall can be satisfactorily modeled using Hardening soil model.
\end{abstract}

Keywords: Deep Excavation, Finite Element, Pre-Stressed Tie Back Anchors, Contiguous Pile Wall, Plaxis, Horizontal Deflection, Ground Settlement

\section{Introduction}

When the shallow foundations were not able to support the structure, deep foundations are required to carry the applied load to the hard strata. If the required stratum was so deep that couldn't be reached by open excavation, then the deep foundation will be used. Deep foundations are Piles, Piers, and Caissons which are mostly used. The mechanism of transfer of the load to the soil is essentially the same in these types of foundations. The choice of which excavations are included in the criteria of deep excavations has been guided by the definition used in the CIRIA report on trenching practice. This study covered trench excavation to a depth of $6 \mathrm{~m}$ (Puller, 2003), as an approximate division between shallow and deep excavations.

In order to build great number of basement levels, especially to obtain parking space and entertainment facilities, deep excavations and construction of retaining structures became compulsory. The depths of the excavation commonly reach to 25 to 40 meters below the ground surface. On the other hand, due to the limited space in urban areas parallel to a rapid development, forced the engineers to provide and apply reliable and suitable construction methods. Deep excavations which are supported by walls are common construction methods. Typically, the excavations in urban areas are supported by different kinds of walls which are internally braced by tieback anchors. In fact, cross-lots and wales struts are 
by far the most used wall supports, but tieback can provide a large working space during construction which is significant construction advantage (Muntohar \& Liao, 2013).

The process of an excavation may encounter different kinds of soils and/or rocks underneath the same excavation site from soft clay to hard rocks. The closer the construction site to a hillside, the more complicated the geological condition. The geological condition determines the type and construction of retaining system and greatly influences the excavation behavior as well. In addition to the geological condition, the distribution of groundwater also contributes to the excavation behavior (Sütcüoğlu, 2010).

Historically, several excavation bracing systems have been improved. Some of them are now more common; these include soldier beams and lagging, sheet piling, bored pile walls, and slurry walls. The decision for using earth retention system in any particular context is limited by technical performance requirements and construction methods including reliability of execution, with cost considered only after these other issues have been addressed. Selection of an appropriate excavation method and the retaining system necessarily considers many factors, such as depth of cut, area of construction site, subsoil profile and engineering characteristics of soil and/or rock formations, groundwater profile, construction budget, allowable construction period, existence of adjacent excavations, availability of construction equipment, conditions of adjacent buildings, foundation types of adjacent buildings, and so on (Sütcüoğlu, 2010).

Deep excavations can be either braced or unbraced. Deep excavations mostly used in urban areas, in fact nearly all engineering works need some soil excavation such as (buildings, roads, tunnels, bridges water treatment plants). Often as a result of space limitations caused by adjacent buildings, proper line or accesses an earth retention system is needed to allow the soil to be excavated to the depth needed. The first step in the establishing of the shoring systems is determination of the type of the excavation method. Then, the applied loads that will affect the retaining system can be calculated in accordance to the excavation method.

Numerical analysis is capable of modeling different phases of excavation such as soil removing process, strut installation and preloading. However, the accuracy of these models depends on the type of the models chose and the appropriate soil parameters for the analysis (Elhakim \& Tahsin, 2011). In this study finite element analysis is performed using PLAXIS 2D v. 8.5 to model a permanent retaining wall (contiguous pile wall) as plain strain which is located in Antepia project at Gaziantep city in Turkey. This retaining wall is pre-stressed using one level of tie-back anchor and the soil of the ground which is determined from the field tests to be totally limestone, is simulated using a non-linear stress strain behavioral model which is called Hardening soil model.

\section{Methods of Calculation of Deep Excavation Retaining Wall}

An encased retaining system consists of pile-plank walls, spaced bored pile walls, shear bored pile walls, and diaphragm walls. With these systems, which could be implemented embedded and with anchored supports, 30 to $35 \mathrm{~m}$ deep excavations could be implemented (Keleşoğlu, \& Özkan, 2005). The selection of retaining system, which is related to the conditions such as excavation depth, soil conditions, distance of the surrounding structures from the excavation, groundwater condition etc., is generally implemented by using anchors/supports. 
The methods, used for designing an encased deep excavation retaining systems can generally be classified into four major groups (Sağlam, 2006); which are "limit stability", "beam on elastic foundation" in which beam and surface of the retaining system is modeled with arches, "pseudo-finite elements", and "finite elements/finite differences" methods. Empirical and tension-based methods are purposive as regards to design but have limited capacity (Alkaya, \& Yeşil, 2010). Furthermore, deformation- based methods and finite elements programs are defined as more accurate and possible to use for every type of soil condition. On the other hand, the major difficulty of deformation-based methods was caused by the estimation of free-soil displacement values (Goh, 1994).

With the use of professional programs, which utilize finite elements and finite differences methods, by modeling structure-soil interaction more realistically, it is possible to consider the construction phases of a retaining system. By this means, it becomes possible both to estimate the wall moment, shear force, and displacement values in every phase of construction, and the displacements of surrounding structures and soil displacements values in the designing phase; and thus, expected deformations can be calculated (Sağlam, 2006). The process steps of designing of a retaining system are as follows; investigation of the excavation surroundings, soil surveys, geotechnical evaluation, retaining project design, building control, instrumental observation, and determination of the legal problems.

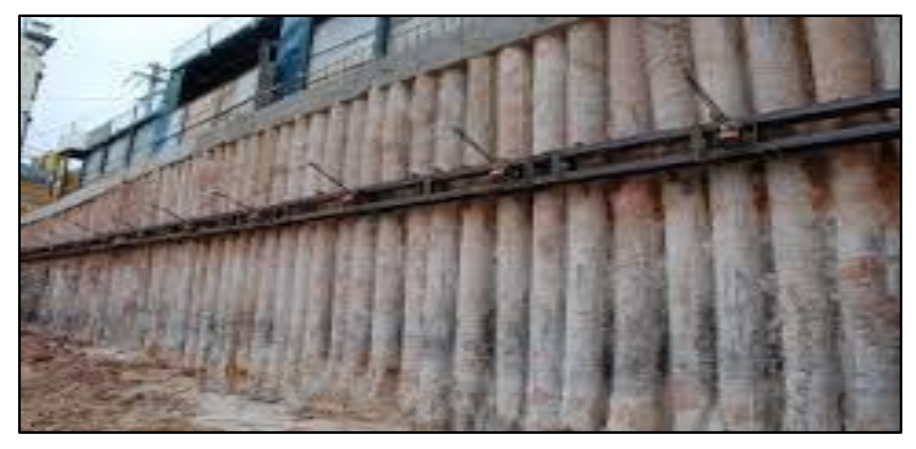

Figure 1: A contiguous pile wall sample

\section{Project Description}

The construction site is included in the Antepia project, which is a huge residential project, being the largest housing project that has so far been implemented in Gaziantep province in Turkey. The project has been established in two stages, stage 1A and stage 1B, which are established on an area of 74, 949, $08 \mathrm{~m} 2$. It consists of many residential buildings, villas, shops and storehouses. The project which has been studied in this article is a braced retaining wall that is located between stage $1 \mathrm{~A}$ and stage $1 \mathrm{~B}$ of the Antepia project and it is going to be constructed with the construction of stage 1B, figure (1.2). The braced retaining wall is shown by a red dashed line that separates stage 1A from stage $1 \mathrm{~B}$ and sustains the soil weight that may be exerted by soil ground of stage 1A during excavation of the soil in stage 1B, (Stage 1B of the Antepia project has not been constructed yet).

The length of the braced retaining wall is $270.80 \mathrm{~m}$. The piles are consisting of two types; one is the piles having $17 \mathrm{~m}$ length which are locating at the first $135.70 \mathrm{~m}$ from the right side of the wall, and the rest of the piles are $19 \mathrm{~m}$ in length. Due to the difference in the length of the piles, two sections are 
taken two be analyzed, section (A-A) and section(C-C). The left side of the wall has an elevation of +906.70 ; it is the top of a retaining wall in sections (A-A) and the top of a water storage (box culvert) in section (C-C) which are constructed before, and $4.65 \mathrm{~m}$ higher than the top surface of the bored piles having an elevation of +902.05 as shown in the figure (4).

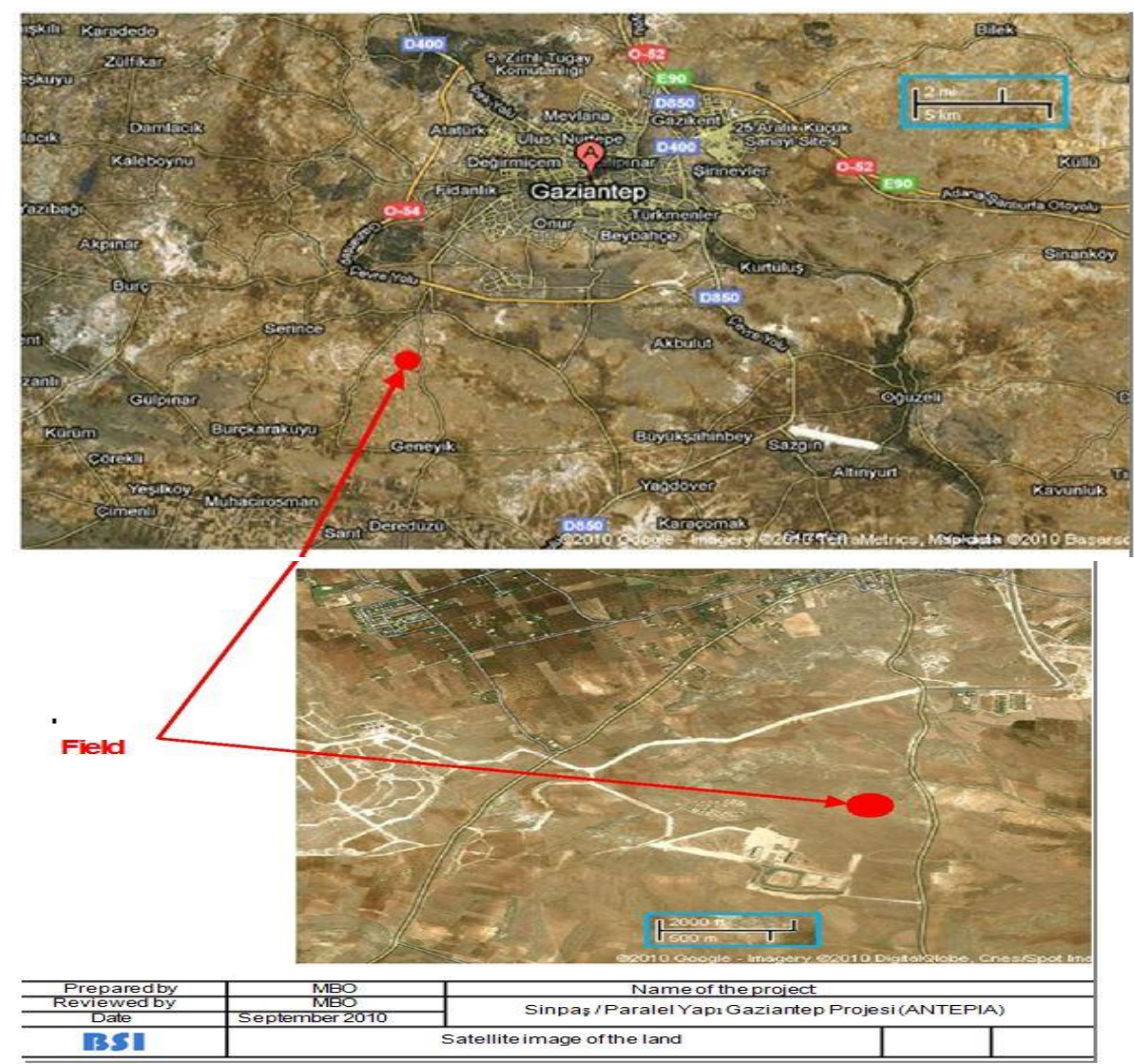

Figure 2: Working Area (Gaziantep/TURKEY) (Satellite images, 2010)

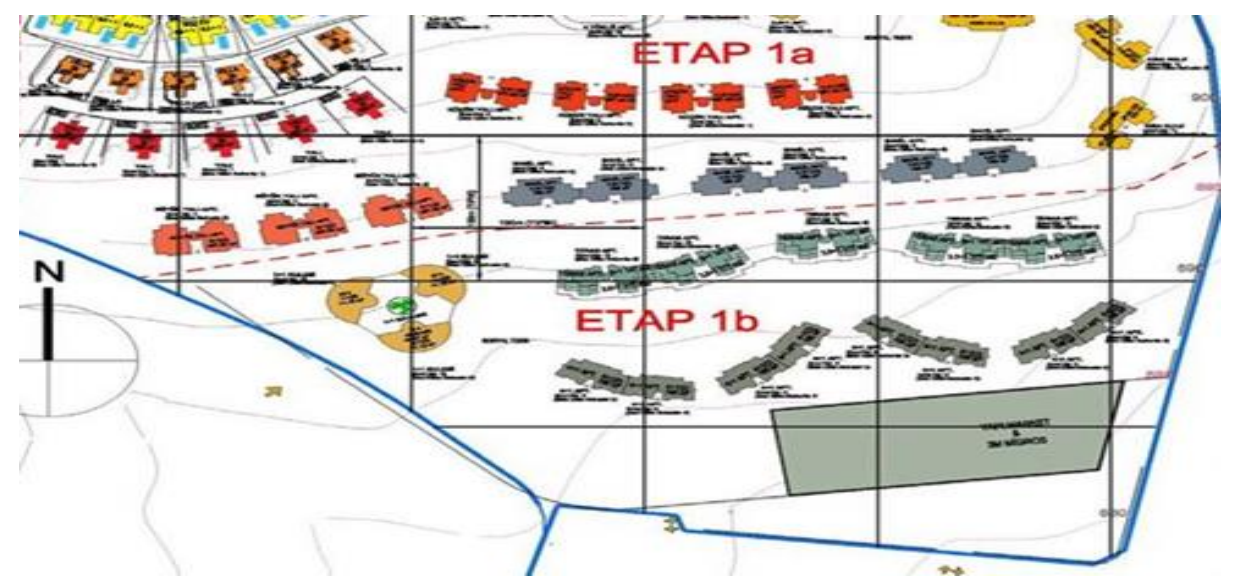

Figure 3: Working Area (Gaziantep/TURKEY) 

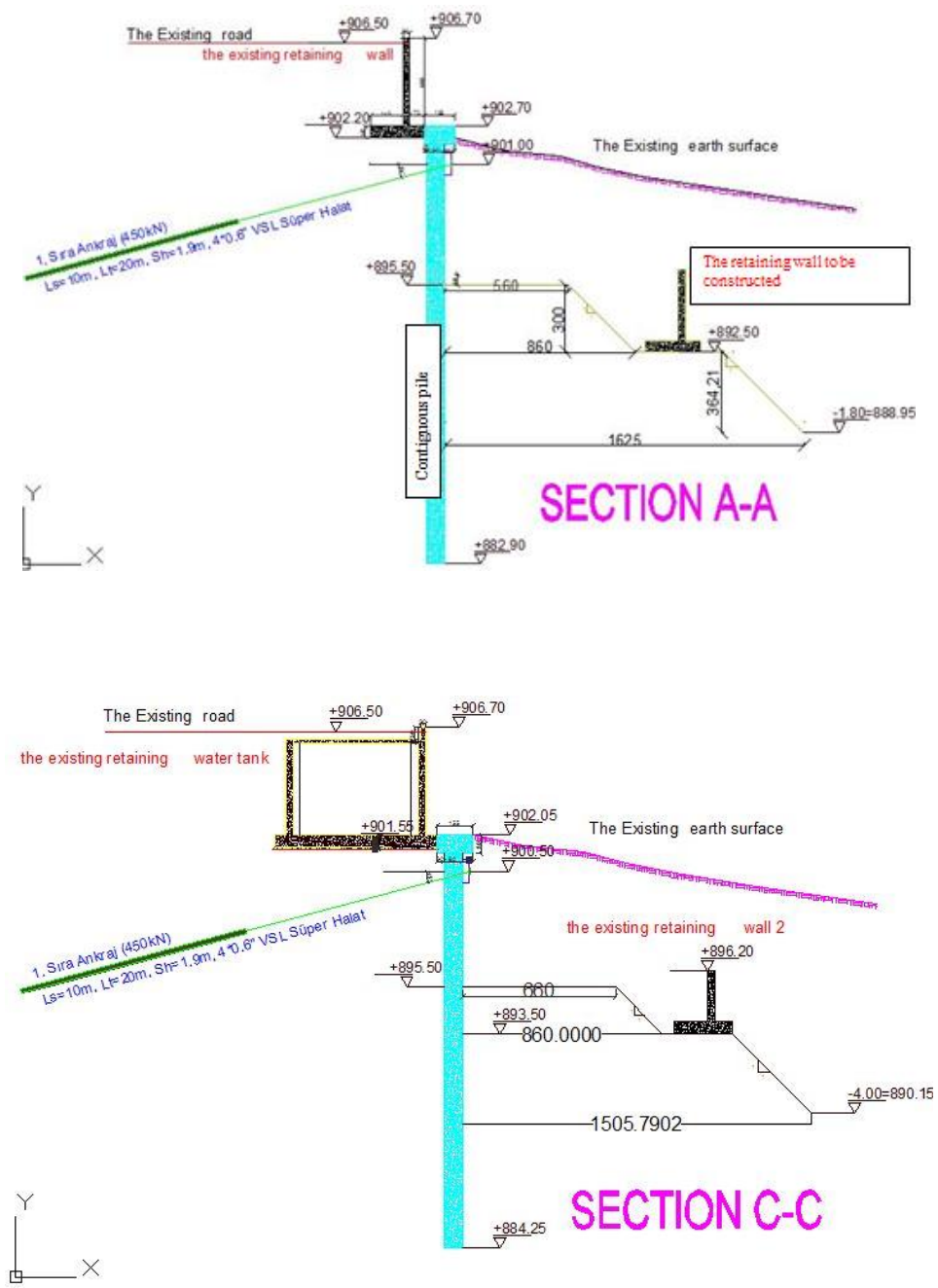

Figure 4: Section A-A and Section C-C of the wall

Section (A-A) represents the group of piles having a length of $19 \mathrm{~m}$, and sections (C-C) are the piles having the length of $17 \mathrm{~m}$. In the left side at the elevation of +906.50 there exists a roadway and parking area. The ground surfaces start from the elevation of +902.05 which will be excavated in four stages to the elevation of +882.9 and +884.25 in section (A-A) and (C-C) successively, after which the contiguous piles have been bored and casted.

\section{Geotechnical Specifications}

The site and laboratory work, to determine the geotechnical specifications of the soil, was directed by a private company. 27 boreholes have been drilled around the braced retaining wall. The field tests which have been carried out are; Pressure meter test, PS logging test and permeability test. The laboratory tests are; rock quality designation test, uniaxial compressive strength and Point load test. From the field and laboratory test results, it is seen that; the first $(0.05-0.3) \mathrm{m}$ width of the ground composes of agricultural soil deposits. Subsequently, at least $2.70 \mathrm{~m}$ up to $10.90 \mathrm{~m}$ thick, with a varying thickness, the ground composes of altered limestone; the altered limestone constitutes of dispersible, fragmented, locally oxidized, accordingly gravel-block-size grains, and locally clayed limestone can be seen. The properties of the soil are given in the table (1). 


\section{Design}

Due to the significance of city route, as well as the constructions localized near excavation and economical aspects, in the design stage contiguous pile wall as retaining structure was assumed. The structure consists of two different sections which have some differences in their structure. Section (AA) consists of a retaining wall which is previously constructed behind the Contiguous pile wall at the elevation of +906.70 and extends to the elevation of +902.70 , then another retaining wall is going to be constructed in front of the contiguous pile wall at the elevation of +896.20 . While section $(\mathrm{C}-\mathrm{C})$ differs from section (A-A) by comprising a water storage tank (box culvert) which is previously constructed, figure (4).

\subsection{Finite Element Analysis}

Finite element method is a numerical analyses method that has an optimal formulation for computer software programs. This is due to the systematic programing in solving complex and difficult problems of the complex boundary conditions and nonlinear material behaviors of the non-homogeneous materials. On the other hand, this method can be applied to a wide area of engineering problems (Belirgen, 1996).

Finite element method should use accurate modelling procedures for; a correct construction sequence, accurate geometry of the excavation, detailed retaining structure, a reliable input parameters and material models. The most important aspect with the finite element method is selecting an appropriate model for structures and soils, construction procedure simulations and soil/structure interface modelling (Potts, Zdravković, Addenbrooke, Higgins, \& Kovačević, 2001). The finite element analysis was carried out by PLAXIS v. 8.5. which is a finite element method developed for numerical analysis of geotechnical engineering problems, as well as it has ability to design and analyze stability and deformations of the geotechnical engineering problems. It is well suited for the analysis of deep excavations supported to be built step by step on the land (Çil, 2007). In this study in order to simulate the soils, both Hardening soil model and Mohr-Coulomb model have been used. The limestone which constitutes the entire model is simulated by Hardening soil model and the fill areas which carried out at the end of the construction stages is simulated by Mohr-Coulomb model.

\subsection{Modeling of the Project}

The model consists of five materials. Soil, Contiguous pile, two retaining walls, a water tank and a Prestressed anchor. Plain strain option chose for modeling the geometry of the project and a 15-node triangle element used to create the mesh. In all cases a drained material has been selected, so the soil friction angle and the cohesion are involved. 
Table 1: Soil and interface properties

\begin{tabular}{|c|c|c|c|c|}
\hline Parameters & Name & Limestone & Fill & Units \\
\hline \multicolumn{5}{|l|}{ General } \\
\hline $\begin{array}{l}\text { Material Model } \\
\text { Type of material model } \\
\text { Soil unit weight above phreatic level } \\
\text { Soil unit weight below phreatic level }\end{array}$ & $\begin{array}{l}\text { Model } \\
\text { Type } \\
\text { Yuns. } \\
\text { Ysat. }\end{array}$ & $\begin{array}{l}\text { Hardened soil } \\
\text { Drained } \\
21 \\
24\end{array}$ & \begin{tabular}{|l|} 
Mohr-Coulomb \\
Drained \\
16 \\
20
\end{tabular} & $\begin{array}{l}- \\
- \\
\mathrm{KN} / \mathrm{m}^{3} \\
\mathrm{KN} / \mathrm{m}^{3}\end{array}$ \\
\hline \multicolumn{5}{|l|}{ Parameters } \\
\hline $\begin{array}{l}\text { Secant stiffness in standard drained triaxail test } \\
\text { Tangent stiffness for primary oedometer } \\
\text { loading } \\
\text { Unloading / reloading stiffness } \\
\text { Power for stress level dependency on stiffness } \\
\text { Cohesion } \\
\text { Friction angle } \\
\text { Dilatancy angle }\end{array}$ & $\begin{array}{l}\mathrm{E}_{50}^{\text {ref }} \\
\mathrm{E}_{\text {oed }}^{\text {ref }} \\
\mathrm{E}_{\text {ur }}^{\text {ref }} \\
m \\
c \\
\varphi \\
\psi\end{array}$ & $\begin{array}{l}150000 \\
150000 \\
450000 \\
0.5 \\
20 \\
35 \\
2\end{array}$ & $\begin{array}{l}15000 \\
- \\
- \\
- \\
1 \\
30 \\
0\end{array}$ & $\begin{array}{l}\mathrm{KN} / \mathrm{m}^{2} \\
\mathrm{KN} / \mathrm{m}^{2} \\
\mathrm{KN} / \mathrm{m}^{2} \\
- \\
\mathrm{KN} / \mathrm{m}^{2} \\
- \\
-\end{array}$ \\
\hline \multicolumn{5}{|l|}{ Flow parameters } \\
\hline $\begin{array}{l}\text { Permeability in horizontal direction } \\
\text { Permeability in vertical direction }\end{array}$ & $\begin{array}{l}\mathrm{K}_{\mathrm{x}} \\
\mathrm{K}_{\mathrm{y}}\end{array}$ & $\begin{array}{l}4.3 \\
4.3\end{array}$ & $\begin{array}{l}1 \\
1\end{array}$ & $\begin{array}{l}\mathrm{m} / \mathrm{d} \\
\mathrm{m} / \mathrm{d}\end{array}$ \\
\hline \multicolumn{5}{|l|}{ Interface } \\
\hline $\begin{array}{l}\text { Interface strength } \\
\text { Strength reduction factor }\end{array}$ & $\begin{array}{l}- \\
\mathrm{R}_{\text {inter }}\end{array}$ & $\begin{array}{l}\text { Manual } \\
0.85\end{array}$ & $\begin{array}{l}\text { Manual } \\
0.65\end{array}$ & $\begin{array}{l}- \\
-\end{array}$ \\
\hline \multicolumn{5}{|l|}{ Initial } \\
\hline $\begin{array}{l}\mathrm{K}_{\mathrm{o}} \text { determination } \\
\text { Lateral earth pressure coefficient } \\
\text { Over-consolidation ratio } \\
\text { Pre-overburden ratio }\end{array}$ & $\begin{array}{l}- \\
\mathrm{K}_{\mathrm{o}} \\
\text { OCR } \\
\text { POP }\end{array}$ & $\begin{array}{l}\text { Automatic } \\
0.47 \\
1 \\
0\end{array}$ & $\begin{array}{l}- \\
- \\
- \\
-\end{array}$ & $\begin{array}{l}- \\
- \\
-\end{array}$ \\
\hline
\end{tabular}

\subsection{Construction Phases}

1) After boring and casting the piles, the ground will be excavated to the elevation of +900.6 in the section $(\mathrm{A}-\mathrm{A})$ and +900.10 in the section $(\mathrm{C}-\mathrm{C})$.

2) The anchor hole is drilled at the elevation of +901.00 and +900.5 for section (A-A) and (C-C) successively.

3) Installation of the anchor tendon will be done, and then prestressed with $400 \mathrm{KN}$ per anchor which has been designed previously. It is decided to use a $20 \mathrm{~m}$ anchor, which contains four tendon strands with $10 \mathrm{~m}$ unbonded zone and $10 \mathrm{~m}$ bonded zone.

4) Excavation to the elevation of +895.50 is carried out in all the sections.

5) Third excavation level is performed in a distance of $8.60 \mathrm{~m}$ from the right side of the pile with angle of $45^{\circ}$ at the elevation of +892.50 in the section (A-A) and elevation +893.50 in the section $(\mathrm{C}-\mathrm{C})$.

6) Then fourth excavation level is performed at a distance of $16.25 \mathrm{~m}$ from the right side of the piles at an angle of $45^{\circ}$ at the elevation +888.95 in the section (A-A), and at a distance of $15.05 \mathrm{~m}$ at the elevation of +890.15 in the section (C-C).

7) Later the second retaining wall will be constructed in order to retain the soil of the left side from descending to the right side where the construction of the apartments exists. 
8) Then a back-filling process is going to be carry out, the fourth excavated level is back filled to the elevation of +892.5 in the section (A-A), and to the elevation of +893.5 in the section of (C-C). Also, the pit behind the second retaining wall in the excavated area is backfilled too.

Table 2: Parameters and properties of Contiguous pile wall

\begin{tabular}{|l|l|l|l|}
\hline Parameter & Name & Value & Unit \\
\hline Material type & Type & $\begin{array}{l}\text { Elastic, } \\
\text { Isotropic }\end{array}$ & - \\
\hline Normal stiffness & EA & $1.59 * 10^{7}$ & $\mathrm{KN} / \mathrm{m}$ \\
\hline Flexural rigidity & EI & $6.3 * 10^{5}$ & $\mathrm{KN} \cdot \mathrm{m} 2 / \mathrm{m}$ \\
\hline Weight & W & 10 & $\mathrm{KN} / \mathrm{m} / \mathrm{m}$ \\
\hline Poisson ratio & V & 0.15 & - \\
\hline
\end{tabular}

Table 3: Properties of the existing retaining wall

\begin{tabular}{|c|c|cc|c|}
\hline \multirow{2}{*}{ Parameter } & \multirow{2}{*}{ Name } & \multicolumn{2}{|c|}{ Value } & Unit \\
& & \multicolumn{2}{|c|}{ Vertical plate Baseplate } & \\
\hline Material type & Type & \multicolumn{2}{|c|}{ Elasotropic } & - \\
\hline Normal stiffness & EA & $9^{*} 10^{6}$ & $1.5^{*} 10^{7}$ & $\mathrm{KN} / \mathrm{m}$ \\
\hline Flexural rigidity & EI & $6.75^{*} 10^{4}$ & $3.12^{*} 10^{5}$ & $\mathrm{KN} \cdot \mathrm{m}^{2} / \mathrm{m}$ \\
\hline Weight & W & 9 & 5 & $\mathrm{KN} / \mathrm{m} / \mathrm{m}$ \\
\hline Poisson ratio & V & 0.15 & 0.15 & - \\
\hline
\end{tabular}

Properties of the contiguous piles, existing retaining wall, second retaining wall, the water tank and the anchorage are all given in the tables 2, 3, 4, 5, 6 and 7 successively.

Table 4: Properties of the second retaining wall

\begin{tabular}{|l|l|lr|l|}
\hline Parameter & Name & \multicolumn{2}{|l|}{$\begin{array}{l}\text { Value } \\
\text { Vertical plate Base plate }\end{array}$} & Unit \\
\hline Material type & Type & \multicolumn{2}{|l|}{ Elastic, Isotropic } & - \\
\hline Normal stiffness & EA & $1.05^{*} 10^{7}$ & $1.5^{*} 10^{7}$ & $\mathrm{KN} / \mathrm{m}$ \\
\hline Flexural rigidity & EI & $1.08^{*} 10^{5}$ & $3.12^{*} 10^{5}$ & $\mathrm{KN} . \mathrm{m} 2 / \mathrm{m}$ \\
\hline Weight & W & 5 & 5 & $\mathrm{KN} / \mathrm{m} / \mathrm{m}$ \\
\hline Poisson ratio & V & 0.15 & 0.15 & - \\
\hline
\end{tabular}


Table 5: Properties of the water tank (Box culvert)

\begin{tabular}{|c|c|c|c|c|c|}
\hline \multirow[b]{2}{*}{ Parameter } & \multirow[b]{2}{*}{ Name } & \multicolumn{3}{|c|}{ Value } & \multirow[b]{2}{*}{ Unit } \\
\hline & & $\begin{array}{l}\text { Right, } \\
\text { Left } \\
\text { Vertical } \\
\text { plates }\end{array}$ & $\begin{array}{l}\text { Base } \\
\text { plate }\end{array}$ & Top Plate & \\
\hline Material type & Type & \multicolumn{3}{|c|}{ Elastic, Isotropic } & - \\
\hline Normal stiffness & EA & $9 * 10^{7}$ & $1.5^{*} 10^{7}$ & $5.1^{*} 10^{6}$ & $\mathrm{KN} / \mathrm{m}$ \\
\hline Flexural rigidity & EI & 6750 & $3.12 * 10$ & $0^{5} \quad 1.23 * 10^{4}$ & KN.m $2 / \mathrm{m}$ \\
\hline Weight & $\mathrm{W}$ & 24 & 13 & 24 & $\mathrm{KN} / \mathrm{m} / \mathrm{m}$ \\
\hline Poisson ratio & V & 0.15 & 0.15 & 0.15 & - \\
\hline
\end{tabular}

Table 6: Properties of the Anchor (Note-to-Note)

\begin{tabular}{|l|l|l|l|}
\hline Parameter & Name & Value & Unit \\
\hline Material type & Type & Elastic & - \\
\hline Normal stiffness & EA & $4.1 * 10^{5}$ & KN \\
\hline Spacing out of plane & Ls & 1.9 & M \\
\hline
\end{tabular}

Table 7: Properties of the grouted body (Geogride)

\begin{tabular}{|c|c|c|c|}
\hline Parameter & Name & Value & Unit \\
\hline Material type & Type & Elastic & - \\
\hline Normal stiffness & EA & $3.6^{*} 10^{5}$ & KN \\
\hline
\end{tabular}

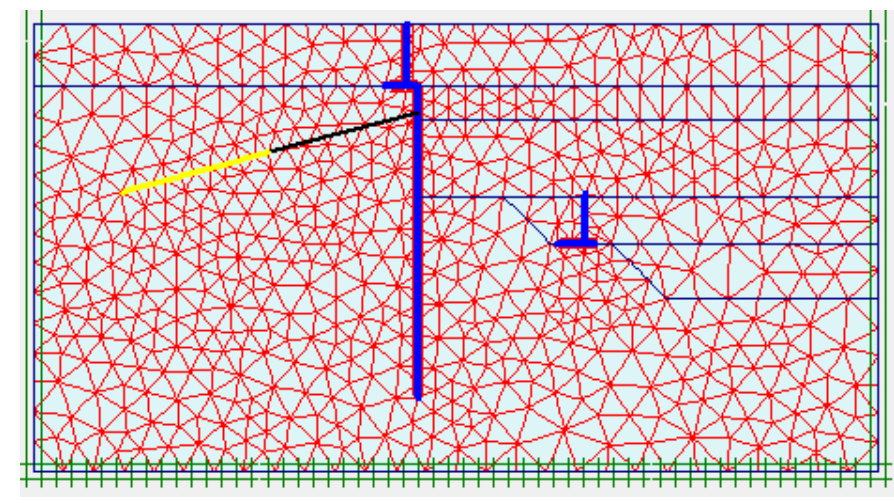

Figure 5: The FEM mesh for section (A-A) 


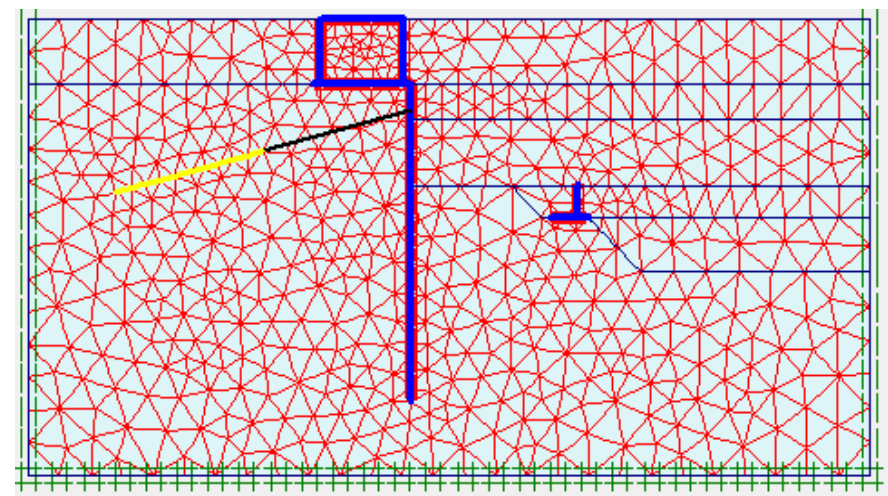

Figure 6: The FEM mesh for section (C-C)

\section{Results}

The maximum ground horizontal displacement of the section (A-A) is $4.12 \mathrm{~mm}$, which occurs at the top-edge of the existing retaining wall behind the contiguous pile. Also, the maximum settlement of the ground is $1.5 \mathrm{~cm}$, which is equal to $0.1 \mathrm{H}$ ( $\mathrm{H}$ is excavation depth). This can be calculated as the following:

$1.5 \mathrm{~cm} / 13.84(\mathrm{H})=0.12 \mathrm{H}$.

The horizontal displacement of the contiguous pile wall is found to be $1.2 \mathrm{~mm}$.

The bending moment and the shear force of the contiguous pile are calculated to be $120.67 \mathrm{KN}$.m and $119.48 \mathrm{KN}$ successively.

The maximum ground horizontal displacement of the section $(\mathrm{C}-\mathrm{C})$ is $14.70 \mathrm{~mm}$, which occurs at the top-edge of the water storage tank behind the wall. Also, the maximum settlement of the ground is $6.53 \mathrm{~mm}$, which is equal to $0.04 \mathrm{H}$ ( $\mathrm{H}$ is excavation depth). This can be calculated as the following:

$0.65 \mathrm{~cm} / 12(\mathrm{H})=0.04 \mathrm{H}$.

Also, the horizontal displacement of the contiguous pile wall is found to be $2.3 \mathrm{~mm}$.

The bending moment and the shear force of the contiguous pile are calculated to be $102.02 \mathrm{KN} . \mathrm{m}$ and 115.47 KN successively.

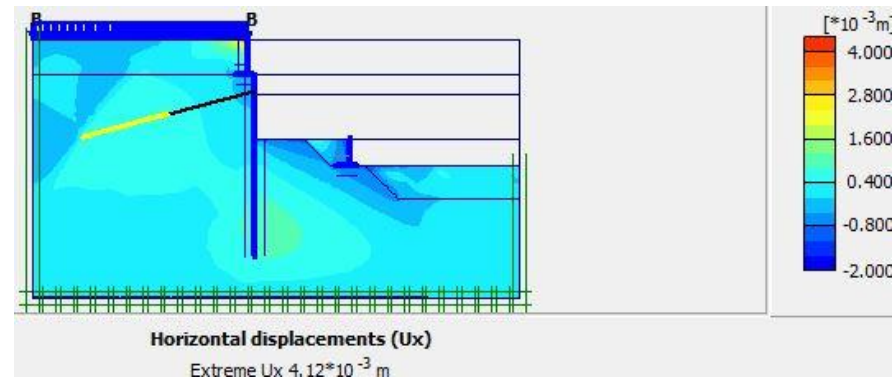

Figure 7: Ground horizontal displacement of section (A-A) 


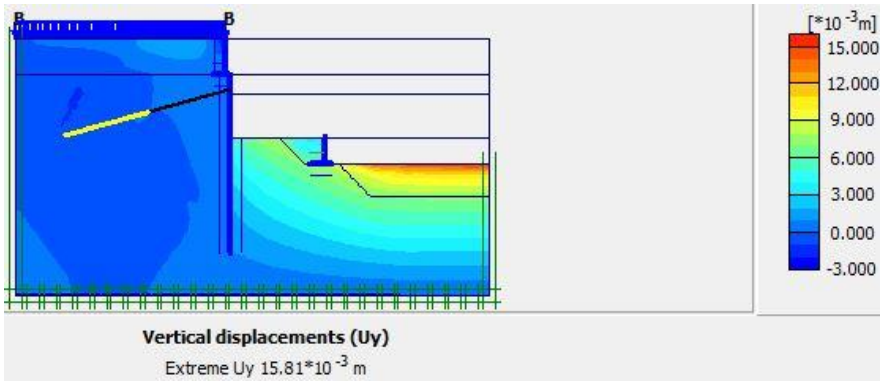

Figure 8: Maximum ground settlement of section (A-A)

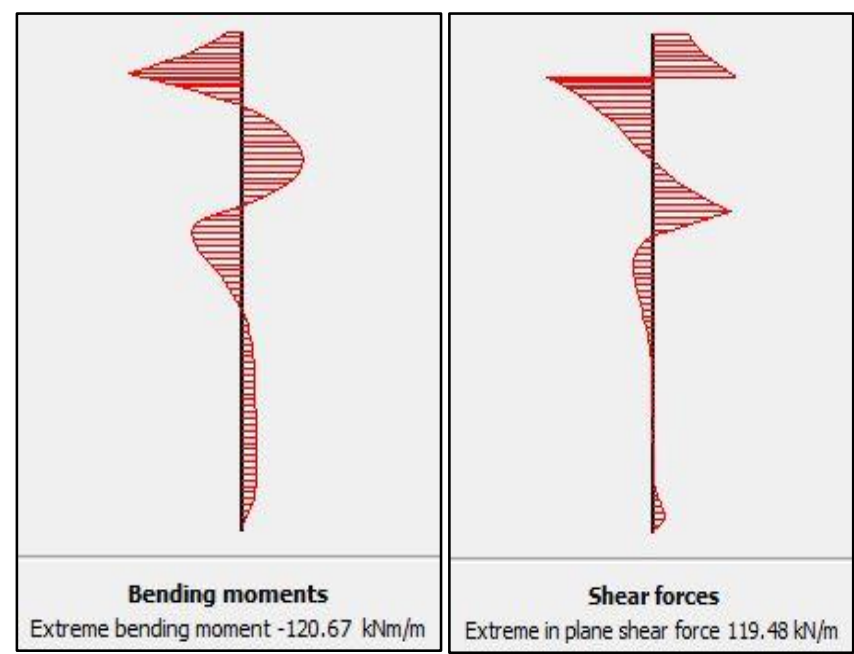

Figure 9: Bending moment and shear force of the contiguous pile wall section (A-A)

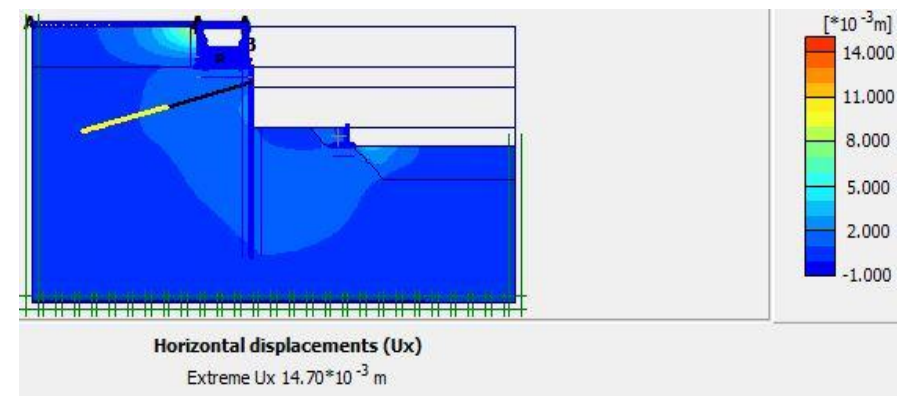

Figure 10: Ground horizontal displacement of section (C-C)

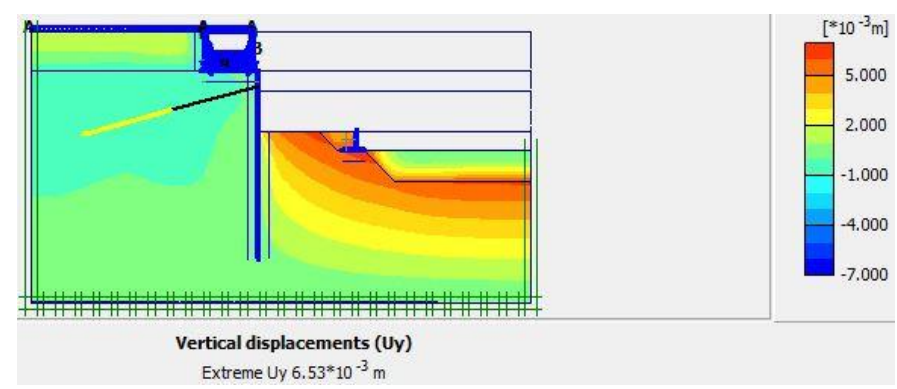

Figure 11: Maximum ground settlement of section (C-C) 


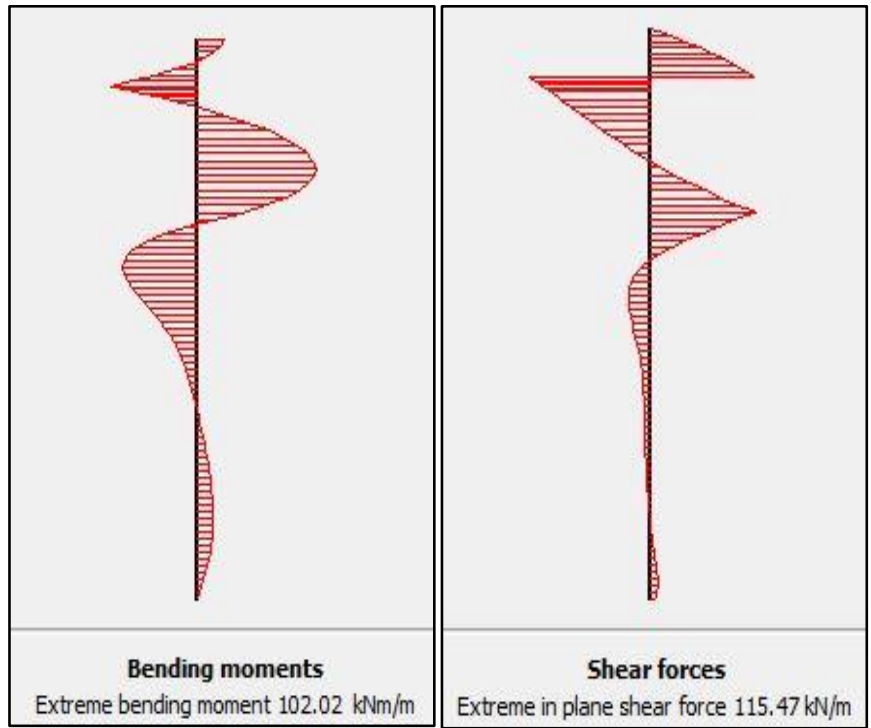

Figure 12: Bending moment and shear force of the contiguous pile wall section (C-C)

\section{Discussion}

Deep excavations and construction of retaining structures became compulsory in order to build various number of basement levels. Many factors should carefully be considered to select the most appropriate excavation method. These factors include, area of construction site, depth of cut, subsoil profile and engineering characteristics of soil and/or rock formations, groundwater profile, allowable construction period, construction budget, existence of adjacent buildings, availability of construction equipment, conditions of adjacent buildings, foundation types of adjacent buildings. Consequently, the need for construction of high-rise buildings and shopping malls with multiple basement levels increased noticeably. Therefore, deep excavation and retaining structures which commonly reach tenth of meters below the ground surface have been constructed especially in the last decade. In this study, in order to analyze the project more precisely the soil models (limestone and fill) have been modelled using both Mohr-Coulomb and Hardening soil models (the limestone is modeled with Hardening soil and fill is modelled with Mohr Coulomb). There are some main differences between them which are summarized below;

According to Mohr Coulomb approach the soil stiffness, taken as E50, is constant throughout the elastic zone, until the stress state reaches the plastic (failure) zone. In reality, the soil behaves nonlinearly which means the soil stiffness is never constant, instead it changes with the stress level within the soil mass. Therefore, at stress level less than $50 \%$ of the ultimate strength, the MC model will overpredict the ground movement, whereas at stress level higher than 50\% (means factor of safety less than 2 ) it can dangerously under predict the ground movement. Also, it assumed the soil unloading reloading stiffness modulus, Eur, equal the soil loading stiffness, E50, i.e. Eur=E50. In reality, under unloading-reloading condition soils generally have much stiffer modulus compared to under loading condition. This means that when applied to evaluate excavation problems, the MC model will generally over predict the soil heave in an unrealistic manner.

According to Hardening soil model, three different stiffness are used in the soil stimulation process which are stiffness, E50, the unloading-reloading modulus, Eur, and the odometer modulus, Eoed. 
This results in a better and more precisely prediction of the soil movement. Indeed, during deep excavation construction, soil behavior differentiates with respect to soil cluster's location to the construction site.
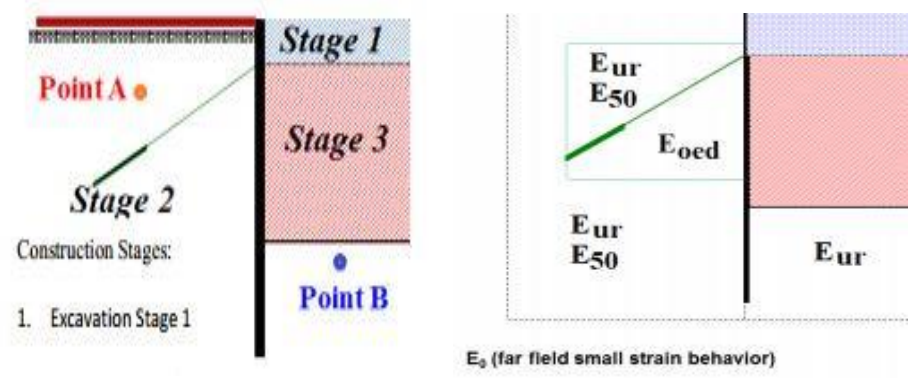

Figure 13: Expected material behavior in excavation problem

Figure (13) shows a typical excavation problem with the stress paths experienced by soil mass below the excavation level and behind the retaining wall. It is clearly demonstrated that the soils at point $\mathrm{B}$ (below the excavation level) undergo unloading case at all construction stages, while point A (behind the retaining wall) goes through several changes, at stage 1 it undergoes unloading, at stage 2 (prestressing) it undergoes reloading, and at stage 3 again it undergoes unloading. The stress paths clearly illustrated the need to use different soil stiffness in evaluating excavation problems.

After analyzing of the project, it is seen that the horizontal lateral displacement of the walls (contiguous pile wall) which has been shown is satisfied with the historical cases. It is seen that these results are convenient with 300 individual case histories. The maximum lateral wall displacement in the sections (A-A and C-C) are 1.2 and $2.3 \mathrm{~mm}$ which are between $(0.008 \mathrm{H}$ and $0.02 \mathrm{H})$ successively. According to Long (2001) for Stiff soils overlaid with soft soils of thickness, the average $\delta \mathrm{hm} / \mathrm{H}$ for CPW (contiguous pile) constructed by the bottom-up method, is 0.47 (Wang, Xu, \& Wang, 2010). Also, according to Moorman (2004) the analysis indicates that in sand and gravels and as well as in stiff clays the maximum horizontal wall displacement reaches uhmax $/ \mathrm{H} \leq 0.35 \%$ (Moormann, 2004).

On the other hand, the maximum ground settlements are $15 \mathrm{~mm}$ and $6.5 \mathrm{~mm}$ for (A-A and C-C) sections successively which are ranging between $(0.12 \mathrm{H}-0.04 \mathrm{H})$. These results are satisfied by Wang (2009). According to his study, generally the settlement of the ground ranges from $0.1 \% \mathrm{H}$ to $0.8 \% \mathrm{H}$ with an average value of $0.42 \% \mathrm{H}$ (Wang, Xu, \& Wang, 2010). But it should be remembered that, these analysis results are not confirmed from field instrumentation data because excavation in Antepia block $1 \mathrm{~b}$ hasn't started yet. The analysis will be verified by the detailed instrumentation results.

\section{References}

Alkaya, D., \& Yeşil, B. (2010). Structure of excel with vba design of anchored retaining and without anchored retaining. Electronic J. Construction Technol, 6(1), 71-82.

Belirgen, M. M. (1996). Ankrajlı perdelerde zemin yapı etkileşiminin incelenmesi.

Çil, T. B. (2007). Iksa sistemleri ve analiz yöntemleri plaxis paket programı. Çukurova Üniversitesi, inşaat Mühendisliği Bölümü, Yüksek lisans Tezi, Adana, Turkey.

Elhakim, A., \&Tahsin, A. (2011). The effect of anchor post-tensioning on the behaviour of a double anchored diaphragm wall embedded in clay. In Proceedings of the 15th African Regional 
Conference on Soil Mechanics and Geotechnical Engineering: Resource and Infrastructure Geotechnics in Africa: Putting Theory Into Practice (p. p. 215). IOS Press.

Goh, A. T. C. (1994). Estimating basal-heave stability for braced excavations in soft clay. Journal of Geotechnical Engineering, 120(8), 1430-1436.

Keleşoğlu, O., \& Özkan, M. Y. (2005, October 26 - 27 ). Embankment induced displacements on laterally loaded piles. p. Civil Engineering.

Moormann, C. (2004). Analysis of wall and ground movements due to deep excavations in soft soil based on a new worldwide database. Soils and Foundations, 44(1), 87-98.

Muntohar, A.S., \& Liao, H.J. (2013). Finite element analysis of the movement of the tie-back wall in alluvial-silty soils. Procedia Engineering, 54, pp.176-187.

Potts, D. M., Zdravković, L., Addenbrooke, T. I., Higgins, K. G., \& Kovačević, N. (2001). Finite element analysis in geotechnical engineering: application (Vol. 2). London: Thomas Telford.

Puller, M. (2003). Deep excavations: A practical manual. London: Thomas Telford.

Sağlam, A. (2006). Stability problems of deep excavations and determinating solution criteria. Sakarya-Turkey: Sakarya University Institute of Science (Doctoral dissertation, Master Thesis).

Sütcüoğlu, M. (2010). A case study: A deep retaining system construction with prestressed anchor. Dokuz Eylül University, 2-3.

Wang, J. H., Xu, Z. H., \& Wang, W. D. (2010). Wall and ground movements due to deep excavations in Shanghai soft soils. Journal of Geotechnical and Geoenvironmental Engineering, 136(7), 985-994. 